\title{
Effect of microbiological testing on subsequent mid-infrared milk component analysis of the same milk sample ${ }^{1}$
}

\author{
Karen L. Wojciechowski, Caterina Melilli, and David M. Barbano ${ }^{2}$ \\ Cornell University Department of Food Science, Northeast Dairy Foods Research Center Ithaca, NY 14853
}

\begin{abstract}
Our objectives were to determine if mixing and sampling of a raw milk sample at $4^{\circ} \mathrm{C}$ for determination of total bacteria count (TBC) and if incubation at $14^{\circ} \mathrm{C}$ for $18 \mathrm{~h}$ and sampling for a preliminary incubation (PI) count influenced the accuracy of subsequent fat, protein, or lactose measurement by mid-infrared (IR) analysis of milk from the same sample container due to either nonrepresentative sampling or the presence of microbial metabolites produced by microbial growth in the milk from the incubation. Milks of 4 fat levels (2.2, 3,4 , and $5 \%$ ) reflected the range of fat levels encountered in producer milks. If the portion of milk removed from a cold sample was not representative, then the effect on a milk component test would likely be larger as fat content increases. Within the milks at each fat level, 3 treatments were used: (1) 20 vials of the same milk sampled for testing TBC using a BactoScan FC and then used for a milk component test; (2) 20 vials for testing TBC plus PI count followed by component test; and (3) 20 vials to run for IR component test without a prior micro sampling and testing. This was repeated in 3 different weeks using a different batch of milk each week. No large effect on the accuracy of component milk testing [IR fat B (carbon hydrogen stretch) and fat A (carbonyl stretch)] due to the cold milk sample handling and mixing procedures used for TBC was detected, confirming the fact that the physical removal of milk from the vial by the BactoScan FC (Foss Electric, Hillerød, Denmark) was a representative portion of the milk. However, the representativeness of any other sampling procedure (manual or automated) of a cold milk sample before running milk component testing on the same container of milk should be demonstrated and verified periodically as a matter of routine laboratory quality assurance. Running TBC with a BactoScan FC
\end{abstract}

Received January 29, 2014.

Accepted May 10, 2014.

${ }^{1}$ Use of names, names of ingredients, and identification of specific models of equipment is for scientific clarity and does not constitute any endorsement of product by authors, by Cornell University, or by the Northeast Dairy Foods Research Center.

${ }^{2}$ Corresponding author: dmb37@cornell.edu first and then IR milk analysis after had a minimal effect on milk component tests by IR when milk bacteria counts were within pasteurized milk ordinance limits of $<100,000 \mathrm{cfu} / \mathrm{mL}$. Running raw milk PI counts (18 $\mathrm{h}$ of incubation at $13-14^{\circ} \mathrm{C}$ ) with the BactoScan FC before milk component testing by IR milk analysis had an effect on component tests. The effect was largest on fat test results and would decrease the accuracy of milk payment testing on individual producer milks. The effect was most likely due to the absorption of light by bacterial metabolites resulting from microbial growth or other chemical degradation processes occurring in the milk during the PI count incubation, not by the sampling procedure of the BactoScan. The direction of the effect on component test results will vary depending on the bacteria count and the type of bacteria that grew in the milk, and this could be different in every individual producer milk sample.

Key words: BactoScan, infrared, preliminary incubation count

\section{INTRODUCTION}

To ensure accurate payment of dairy farmers for the milk they produce, bulk tank raw milk is mixed and sampled at the farm at every pick up and the amount of milk delivered is measured by weight or volume. In the United States, unpreserved milk samples used for inhibitor and microbial testing under the grade A milk program, as defined in the National Conference on Interstate Milk Shipment (NCIMS) Cultural Procedures 2400 form (Revision 10/13), Item 33a.6.b (NCIMS, 2013), are refrigerated during transit to the laboratory and must arrive at a temperature of 0 to $4.4^{\circ} \mathrm{C}$ and be tested within $60 \mathrm{~h}$ (NCIMS, 2013); whereas for component payment under the US Federal Milk Marketing Order (NCIMS, 2013), testing the unpreserved milk must be completed within $72 \mathrm{~h}$. Historically, samples used for microbial and component testing were placed in separate sample containers at milk collection. However, as farms have gotten larger, the value of milk has increased, and high-speed electronic testing equipment for milk components, somatic cell, and bacteria counting have become available, it has become common 
practice to try to use milk from the same sample container for multiple purposes.

With the advent of automated instrumental methods for measurement of the total bacteria count (TBC) of milk, SCC, and milk composition, a desire to have more frequent measures of the TBC, SCC, and component (i.e., fat, protein, lactose, solids) concentrations in raw milk from individual farms has been observed. In the United States, 1 sample of raw unpreserved milk is taken aseptically by the truck driver at every milk pick-up on every farm. The amount of milk in 1 sample container is adequate to do the electronic microbial, mid-infrared (IR) milk component, and SCC testing. As a result, many large commercial milk testing laboratories have started doing microbiological and component tests by taking a test portion from the same container of milk to avoid the added costs of collection of separate samples. Because of the possibility of microbial contamination and growth in the milk sample after the farm, coupled with the fact that the sample would need to be warmed to $40^{\circ} \mathrm{C}$ for about $10 \mathrm{~min}$ before IR milk analysis promoting bacteria growth, the TBC of the unpreserved milk is done before component testing of a milk sample by removing a test portion of cold milk from the container. Concern exists that handling and sampling for the microbiological TBC electronic milk testing may remove a nonrepresentative portion of the cold (about $4^{\circ} \mathrm{C}$ ) milk sample and cause the component payment testing (particularly fat) to be incorrect.

As raw milk quality premium payment programs became common in the dairy industry (Barbano 1992; Everson 1988; Geyer 1990), a desire was noted to have additional microbial quality tests beyond the TBC that could detect deficiencies on the farm and potentially predict the effect of raw milk microbial quality on pasteurized milk and cheese quality, even though other factors, such as milk SCC, can influence the sensory properties of fluid milk (Ma et al., 2000; Santos et al., 2003a,b; Barbano et al., 2006). Recently, it has become common to conduct a preliminary incubation (PI) count on individual farm milks and bulk milk transfer tankers (Martin et al., 2011) as one approach to further evaluate raw milk quality. The method for application of a PI count to raw milk, as outlined in the 14th (Marth, 1978) and 15th edition (Richardson, 1985) of Standard Methods for Examination of Dairy Products (SMEDP), specified incubation of a 10-mL subsample milk for $18 \mathrm{~h}$ at $12.8^{\circ} \mathrm{C}$ followed by an $\mathrm{SPC}(48 \mathrm{~h}$ at $32^{\circ} \mathrm{C}$ ) or alternative method. It was suggested that if the sample did not represent more than 2 milkings (i.e., only 1 or 2 milkings) that it should be held at 0.0 to $4.4^{\circ} \mathrm{C}$ for an additional $24 \mathrm{~h}$ before starting the incubation. The justification for the raw milk PI method was that the SPC on fresh raw milk may not provide an ac- curate evaluation of sanitation conditions under which the milk was produced. It was suggested that careless milk-handling practices that allowed contamination of the milk at a level, which would not be detected by the SPC on fresh milk, might be detected by the raw milk PI count. Whereas the PI method was referenced in SMEDP, it was not an official regulatory test. At the 1983 NCIMS conference, however, a proposal was submitted to make it an official accepted method under the grade A milk program. This initiated a study by the US Food and Drug Administration, which found no correlation of the PI method to farm inspection scores (Peeler et al., 1989). As a result, the PI method for raw milk was removed from the subsequent 16th (Marshall, 1992) and 17th (Wehr and Frank, 2004) editions for SMEDP. In these editions, only a PI method for pasteurized milk was included, which has caused some confusion for those looking for the original raw milk PI method.

Although the PI count is not an official regulatory method, it has been given credit for helping to improve producer raw milk quality (Bishop, 1989) and continues to be used in this manner. Some have implied that raw milk PI counts can be used as an indicator for dairy product shelf-life potential (Ryan, et al., 1984), but the published data to support this has been lacking. Martin et al. (2011) reported results of an evaluation of the predictive value of various raw milk microbial tests, performed on plant raw milk supplies, including a raw milk PI count $\left(18 \mathrm{~h}\right.$ at $12.8^{\circ} \mathrm{C}$ incubation followed by a SPC) on the shelf-life and sensory quality of pasteurized fluid milk. Martin et al. (2011) concluded that none of the microbial tests commonly used by the dairy industry to screen raw milk have the ability to accurately predict bacterial or sensory quality of pasteurized milk over shelf-life.

Because of its perceived value in improving raw milk quality, the use of the PI count as an additional raw milk test is widespread in producer quality programs. To facilitate its continued and expanded use, larger cooperative laboratories began using the BactoScan FC (Foss Electric, Hillerød, Denmark) as an alternative counting method for raw milks after the PI step, which were traditionally done using plating techniques. The BactoScan FC is an automated flow cytometricbased method used for counting bacteria in raw milk (Suhren et al., 2001; Robinson, 2002; Walte et al., 2005) and is approved for official bacteria counts under the grade A milk program and in other countries. The method requires the staining of the bacteria cells with fluorescent dye (ethidium bromide) that binds to specific cell constituents to distinguish them from other particulate matter in a milk sample. This type of DNA staining-based method eliminates the need for a 
microbial growth step, as required for traditional plate counting, and has made it possible to rapidly determine milk bacteria count in preserved milk samples. In the United States, all of the component payment testing and microbial testing for regulatory purposes are done on unpreserved samples, although this is not the case in some countries in Europe and some other areas of the world, where all samples are preserved and tested using electronic milk testing methods that do not require microbial growth for counting. This is a more rapid method for determining TBC on large numbers of raw milk samples than using traditional bacterial plating and counting technologies. As used for the PI count on unpreserved samples in the United States, it has allowed for more testing and improved efficiencies in laboratories that use the BactoScan FC.

To further improve laboratory efficiencies, a proposal to allow official electronic SCC to be performed on milk held at $13^{\circ} \mathrm{C}$ for $18 \mathrm{~h}$ was submitted to the 2009 NCIMS conference. This was proposed to allow laboratories that use a BactoScan for PI counts of raw milk to run electronic SCC on the same sample. The proposal passed, even though the PI method is not recognized as an official test for grade A raw milks as defined in the NCIMS Cultural Procedures 2400 form (Revision 10/13), item 33a.7a,1 (NCIMS, 2013). The adoption of electronic testing units that combine tests for both components and SCC has also helped improve laboratory efficiencies allowing for more rapid testing from a single sample.

With approved testing for SCC on samples held at $13^{\circ} \mathrm{C}$ for $18 \mathrm{~h}$ for the PI method, the potential for industry laboratories to use these PI samples on separate or combination electronic testing equipment for both components and SCC exists. From a milk component payment testing perspective, concern exists that the 18 -h at 13 to $14^{\circ} \mathrm{C}$ incubation period could cause proteolysis, lipolysis, and microbial metabolite development that could influence both the subsequent mid-IR fat and protein payment tests conducted on the same milk sample. Kaylegian et al. (2007) reported a significant increase $(P \leq 0.05)$ in the mid-IR protein readings with an increase in free FA content, and these findings are consistent with other reports (Robertson et al., 1981; Kerkhof Mogot et al., 1982; van de Voort et al., 1987). The increase in protein reading was due to the absorbance of the carboxylate anions of dissociated free FA (Silverstein and Bassler, 1967) in the wavelength range of 6.06 to $6.45 \mu \mathrm{m}\left(1,650-1,550 \mathrm{~cm}^{-1}\right)$ near the region of the protein sample filter. The principle of mid-IR milk analysis using discrete wavelengths in the IR spectra has been described previously (Barbano and Clark, 1989). Infrared milk analysis assumes that the compounds in the milk sample are only those that came from the cow and the selection of wavelengths (Kaylegian et al., 2009), and calibrations to measure the fat, protein, lactose, and solids concentrations in raw milk are based on that assumption. This is true for both the older filter instruments and the new Fourier transform mid-IR instruments (FTIR)-based milk analyzers. The FTIR instruments can use either a virtual filter approach with a refined version of the traditional wavelengths that were used in the old filter instruments, as described by Kaylegian et al. (2009), or partial lest squares (PLS) calibration prediction models. The effect of other compounds that develop in milk due to microbial growth is less predictable when using PLS models than with the virtual filter approach because the wavelengths used in these statistical prediction models will differ between instrument manufacturers and may be different among instrument models within the same manufacturer. Generally, the wavelengths and the $\beta$ coefficients used for each wavelength in PLS models for predicting fat, protein, lactose, and so on are not provided to the user by the instrument manufacturer due the complexity of the information and proprietary concerns by equipment manufacturers. When other compounds, such as acids (Barbano and DellaValle, 1987), $\mathrm{CO}_{2}$ (Ma et al., 2001), and preservatives (Barbano et al., 2010), are added to milk, an effect on the accuracy of mid-IR milk testing has been observed. Production of lactic acid by the growth and metabolism of lactic starter cultures used in cheese making causes the milk component tests to be inaccurate when trying to test milk samples from cheese vats after starter culture addition. Schmitt and Flemming (1998) used FTIR to identify bacteria in biofilms based on their unique metabolites that absorb light in the mid-IR spectra, and FTIR has become an additional tool for microbial identification, indicating the growth of bacteria in a sample influence the mid-IR spectra.

To address concerns about the potential influence of microbiological testing on accuracy of component payment testing done on milk from the same sample container, a study was designed to determine if the sampling and microbial testing using a BactoScan before component testing has an influence on the component test result. The first objective of our research was to determine if the mixing and sampling of a raw milk sample at $4^{\circ} \mathrm{C}$ by a BactoScan for determination of TBC influenced (mainly due to nonrepresentative sampling) the subsequent fat, protein, or lactose test of the same milk from the same container. The second objective was to determine if sampling by a BactoScan for TBC followed by incubation at 13 to $14^{\circ} \mathrm{C}$ for 18 $\mathrm{h}$ and a second sampling by a BactoScan for PI count influenced the accuracy of subsequent fat, protein, or lactose test of the same milk from the same sample 
container due to either nonrepresentative sampling or presence of microbial metabolites produced by microbial growth in the milk.

\section{MATERIALS AND METHODS}

\section{Experimental Design and Statistical Analysis}

Milks of 4 different fat levels (FL; FL1 $=2.2 \%$, FL2 $=3 \%$, FL3 $=4 \%$, and FL4 $=5 \%$ ) were formulated to obtain 240 vials of milk total (60 vials of the same milk within each fat level). Different FL were used to reflect the range of FL encountered in producer milks and because if the portion of milk removed from a cold sample was not representative, the effect on the milk component test would likely be the largest on the fat test. Within the milks at each FL, 3 treatments were used: (1) 20 vials of the same milk sampled for testing TBC by BactoScan and then used for a milk component test (TBC); (2) 20 vials for testing TBC plus PI count followed by component test (TBC+PI); and (3) 20 vials to run for IR component test without a prior microsampling and testing (IR only). This was repeated in 3 different weeks using a different batch of milk each week. The microbiological sampling and analyses were done in a different NCIMS-approved laboratory each week using a different BactoScan in each laboratory (laboratory 1, 2, and 3) to reflect instrument-to-instrument and operator variation in mixing and sampling.

First, analysis of the IR data was done with the combined data from all 3 laboratories using the GLM (general linear models) procedure of SAS (SAS Institute Inc., Cary, NC). The differences in TBC and TBC+PI from the IR only value for fat $\mathrm{A}$, fat $\mathrm{B}$, protein, and lactose were analyzed using an ANOVA, with terms for laboratory (1, 2, and 3), fat level (FL1, FL2, FL3, and FL4), treatments (IR only, $\mathrm{TBC}, \mathrm{TBC}+\mathrm{PI}$ ), and all the 2-way interaction terms. Data were tested for each term in the model using a $t$-test (LSD, $P<0.05)$. The term for laboratory reflects the fact that each laboratory had a different BactoScan instrument, but also reflects a different batch of raw milk with a different microflora. If a systematic effect of nonrepresentative sampling was noted, one would expect the term for laboratory to be significant and the direction of difference from the IR only treatment would be the same for both the fat $\mathrm{A}$ and fat $\mathrm{B}$ due to a systematic mixing and sampling error that influence both measures of fat in the same direction. If an interaction of laboratory by treatment was significant and the direction of the difference from IR only for fat B and fat A were not in the same direction, then it would indicate that difference in microflora from 1 batch of milk to the next and the production of microbial metabolites caused an absorbance of IR light that produced an error in the IR measurement of milk components. If the 2 -way interaction term of laboratory by treatment was significant, then data would be further analyzed separately for each laboratory (or instrument) using the GLM (general linear models) procedures of SAS. The differences in TBC and $\mathrm{TBC}+\mathrm{PI}$ from the IR only value for fat A, fat B, protein, and lactose were analyzed using an ANOVA, with terms for fat level (FL1, FL2, FL3, and FL4) and treatments (IR only, TBC, TBC+PI) and the interaction of fat level by treatment. Data were tested for each term in the model using a $t$-test (LSD, $P<0.05)$. The fat $\mathrm{B}$, lactose, protein, and fat $\mathrm{A}$ values for the treatment IR only was always a zero reference point with random variation around a mean of zero difference.

\section{Milk Processing and Sample Splitting}

The gravity separation process (Kaylegian et al., 2006a) used to produce milks at 4 fat levels is summarized in Figure 1. Raw bulk tank milk from Holstein cows was collected at the Cornell Teaching and Research Center and transported to the Cornell University Pilot Plant. The raw milk was gravity separated overnight (ca. $22 \mathrm{~h}$ ) at $4^{\circ} \mathrm{C}$. The gravity skim layer (bottom $90 \%$ by weight) was removed from the bottom of the cone-bottom tank first, followed by removal of the cream (the upper 10\% of the weight) in 6 layers [C1 (bottom) to C6 (top)]. The gravity skim milk and each of the cream layers were analyzed for fat content. The C6 layer was the layer with the highest fat content and was used in combination with the gravity skim milk to create milks with $4 \mathrm{FL}$. The FL1 was made from gravity skim milk only (about $2.2 \%$ fat), whereas FL2, FL3, and FL4 were made by adding some C6 cream to the gravity skim to obtain a final fat content of about 3 , 4, and $5 \%$, respectively (Figure 1). Initially, milk at each FL was tested for SCC (AOAC International, 2000; method 13.13.01; 978.26) using Fossomatic (Foss Electric, Hillerød, Denmark) and bacteria by Petrifilm (Wehr and Frank, 2004: method 6.040). Each of the 4 different FL milks (FL1, FL2, FL3, and FL4) was split in sixty $60-\mathrm{mL}$ sterile plastic snap-top vials (CPP02, Capitol Plastic Products, Amsterdam, NY). Within each FL, 20 vials of milk were used for IR only, 20 vials testing TBC by BactoScan, and 20 vials for testing TBC + PI by BactoScan. The overall total of milk samples in each week was 240 (Table 1). All of the vials were held at $4^{\circ} \mathrm{C}$ for $48 \mathrm{~h}$ before the evaluation. The 48-h holding period allowed a cream layer to form in the sample container as normally happens during sample storage and handling before testing. The presence of a fat layer presents a challenge for mixing and representative sampling, and increasing the fat concentration from 2.2 to 
Table 1. Number of vials of milk within each fat level to be analyzed for mid-infrared (IR) only, total bacteria count (TBC), and TBC + preliminary incubation (PI) within each laboratory; a separate batch of milk and set of sample vials was prepared in each of 3 wk for testing in 1 of the 3 laboratories

\begin{tabular}{lccccc}
\hline Fat level (FL) & $\begin{array}{c}\text { Fat } \\
(\%)\end{array}$ & $\begin{array}{c}\text { Vials } \\
\text { for IR }\end{array}$ & $\begin{array}{c}\text { Vials } \\
\text { for TBC }\end{array}$ & $\begin{array}{c}\text { Vials } \\
\text { for PI }\end{array}$ & $\begin{array}{c}\text { Total } \\
\text { vials }\end{array}$ \\
\hline FL1 & 2.2 & 20 & 20 & 20 & 60 \\
FL2 & 3 & 20 & 20 & 20 & 60 \\
FL3 & 4 & 20 & 20 & 20 & 60 \\
FL4 & 5 & 20 & 20 & 20 & 60 \\
Total samples & & & & & 240 \\
\hline
\end{tabular}

about $5 \%$ would increase the size of the cream layer and improve the ability of the experimental design to detect the removal of a nonrepresentative test portion of milk from the vial by a BactoScan testing before the component testing.

A flowchart of the testing of the 60 vials of milk at each fat level is given in Figure 2. From the 60 vials (within each FL), on the first day of analysis, the first group of 20 milks $\left(4^{\circ} \mathrm{C}\right)$ were tested for TBC on Bacto-
Scan. The vials were mixed 10 times by inversion and then the automatic stirring, sampling, and testing by the BactoScan was done. After testing, the 20 milks at FL1 were put back in $4^{\circ} \mathrm{C}$ storage. The second group of 20 vials at FL1 was tested using BactoScan, the same as the first group. However, after testing the second 20 milks for TBC by the BactoScan, the milks were then incubated at 13 to $14^{\circ} \mathrm{C}$ for $18 \mathrm{~h}$ and tested again on the BactoScan for the PI count (second day of analy-

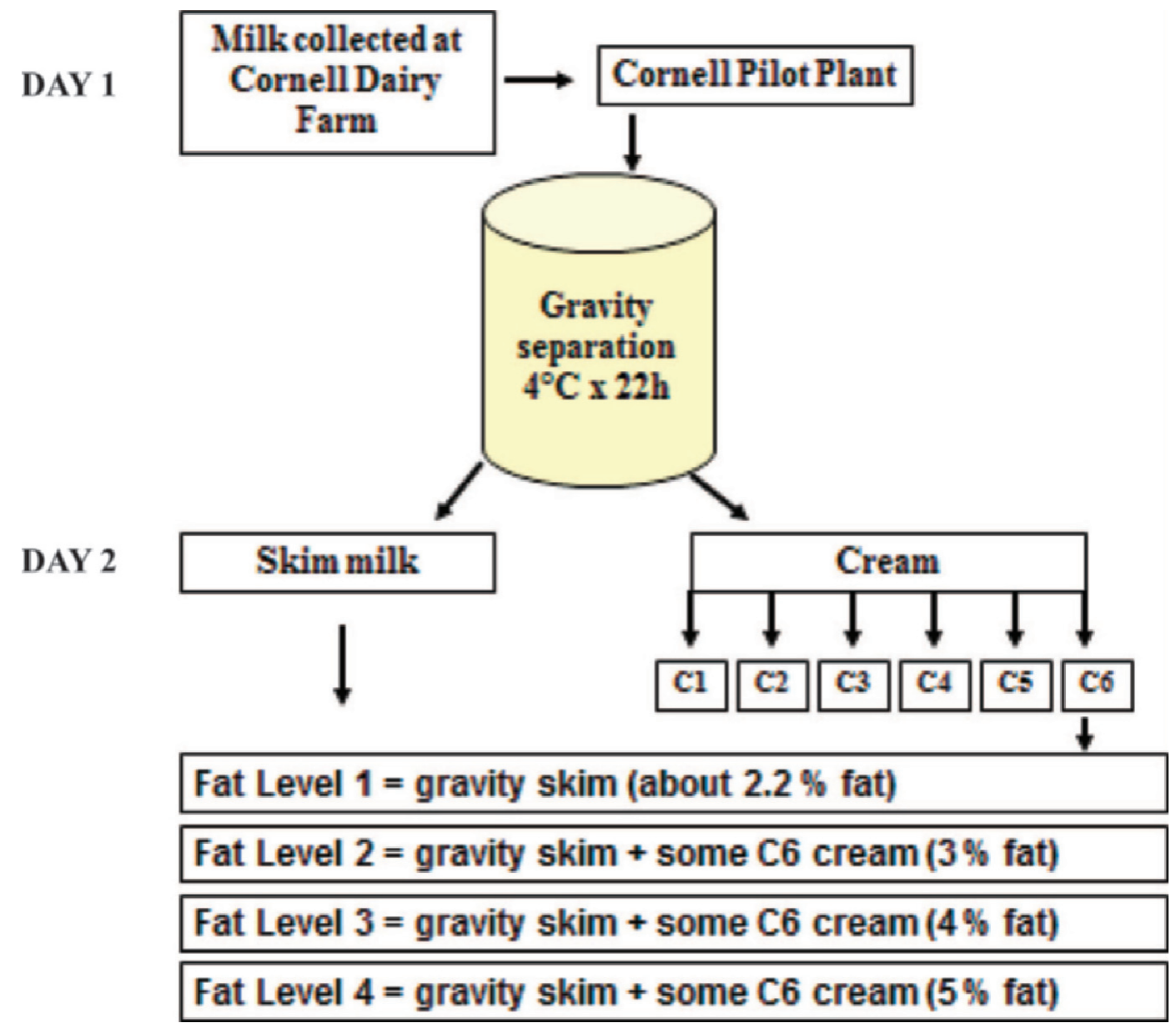

Figure 1. Diagram of the experimental design for preparation of the 4 fractions [fat level (FL) 1, FL2, FL3, and FL4]. Color version available in the online PDF. 
sis). After the PI count, the 20 milks were placed back in a $4^{\circ} \mathrm{C}$ cooler. This sample cooling step to $4^{\circ} \mathrm{C}$ is not needed if the samples are to be tested for components immediately after the BactoScan PI count. However, some labs cool the samples because of logistical and timing issues. In the present study this was done to standardize the conditions in the 3 replicates and allow refrigerated transport of the samples back to the IR milk analyzer where the component testing was done. The third group of 20 out of the 60 milks from each FL was held at $4^{\circ} \mathrm{C}$ without prior microbial sampling until IR testing. This was done for the milks at each of the $4 \mathrm{FL}$. On the third day of analysis, all of the 60 milk samples, within each FL, were warmed at $40^{\circ} \mathrm{C}$ and analyzed for milk components on an IR milk analyzer (Figure 2). This was repeated in 3 different weeks and samples were tested in a different laboratory using a different BactoScan by a different technician. All samples for the current study were tested on the same IR milk analyzer to keep the calibration and conditions of the IR milk analysis well defined and consistent throughout the study.

\section{Microbiological and Milk Component Testing}

Petrifilm SPC. The Petrifilm aerobic plate count method 6.040 was used for the analysis of initial raw milk samples, as described by Wehr and Frank (2004).
BactoScan TBC. The details of the BactoScan method and conversion of individual bacteria count to colony forming units are provided by Surhen et al. (2001) and Walte et al. (2005). The BactoScan was operated according to the procedures outlined in the US Food and Drug Administration, 2400a-2 Foss BactoScan FC BIO Companion Protocol Rev 3/11 (NCIMS, 2011). Milks were kept at 0 to $4^{\circ} \mathrm{C}$ until placed in racks for testing. Sample vials were inverted 10 times to mix before placing into testing racks and testing on the BactoScan. Samples 1 through 20 were tested in order (1 to 20 ) within FL, starting with 20 samples containing $2 \%$ fat and progressively going up to $5 \%$ fat. For example, $2 \%$ fat had a TBC run and then PI, 3\% fat had a TBC run then PI, and so on. One laboratory used a BactoScan FC 50 whereas the other 2 laboratories used BactoScan FC 100 (Foss Electric). The sample mixing and uptake volume are the same for the FC 50 and FC 100 models

BactoScan PI Count. The raw milk PI count was determined using BactoScan on raw milk that was incubated for $18 \mathrm{~h}$ at 13 to $14^{\circ} \mathrm{C}$ before testing a second time on the BactoScan as described in the previous procedure. For the TBC run using the BactoScan on d 1, samples were tested in order (1 to 20) within fat level, starting from the lowest to highest number.

Fat, Protein, Lactose, and Somatic Cell Testing. An initial milk sample was collected at each FL to

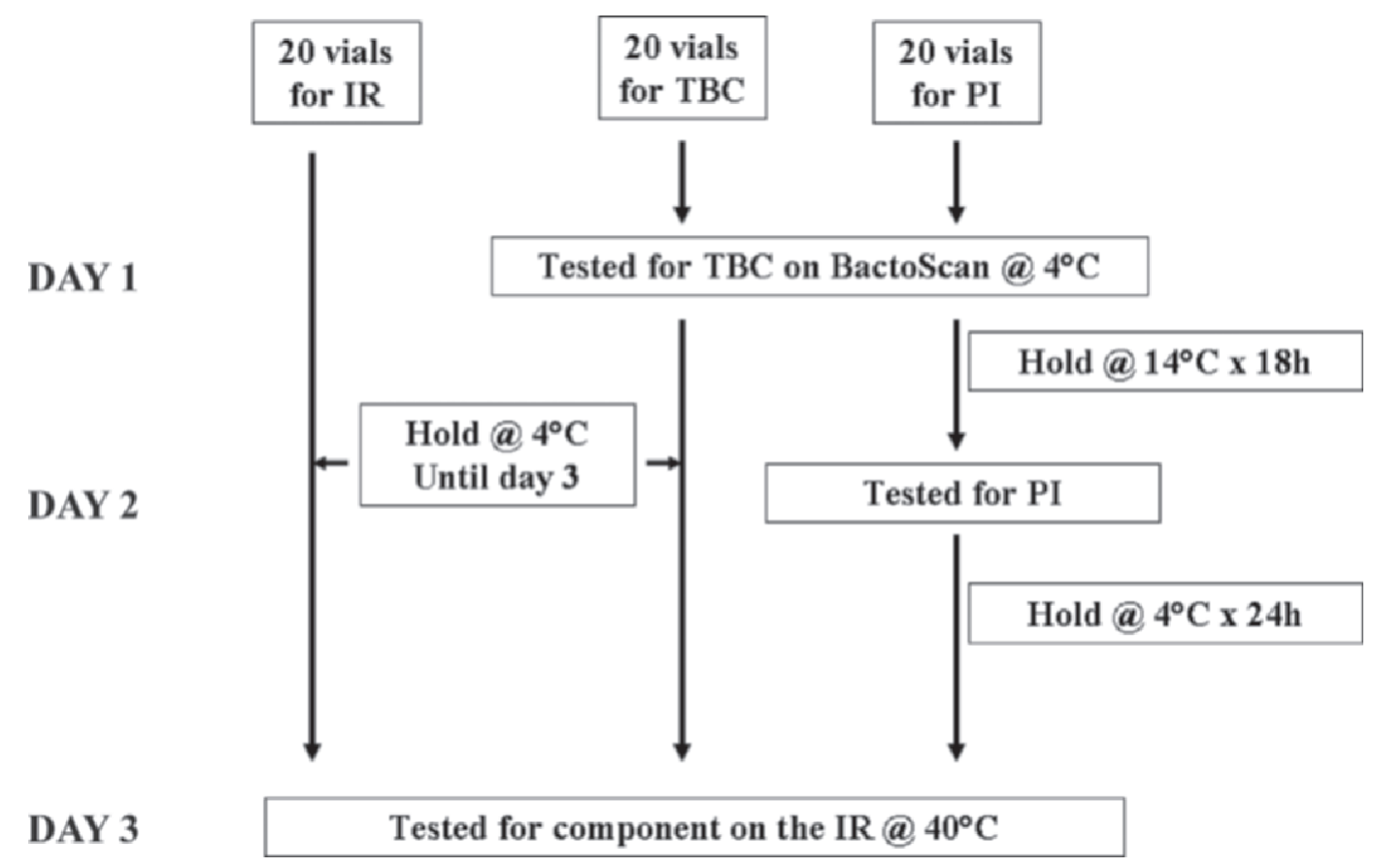

Figure 2. Diagram of testing approach of the 60 samples collected for each fat level of milk. IR = infrared; TBC = total bacterial count; PI $=$ preliminary incubation; BactoScan = BactoScan FC (Foss Electric, Hillerød, Denmark). 
Table 2. Milk composition (percent, mass/mass) measured by mid-infrared transmission fat B, fat A, true protein, and anhydrous lactose for each fat level milk for laboratory (Lab) 1, 2, and 3

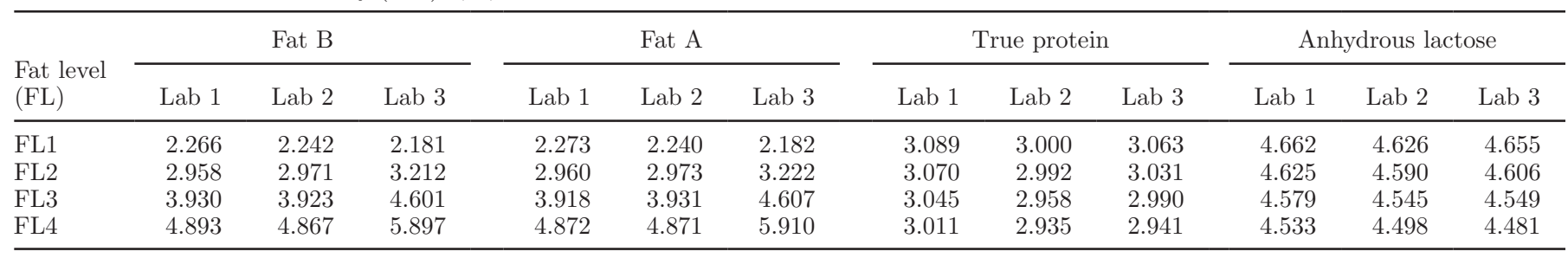

measure SCC using a Fossomatic somatic cell counter (AOAC International, 2000; method 978.26). Infrared milk analysis (AOAC International, 2000; method 972.16) for percent (mass/mass) fat, protein, and lactose was done using the standard optimized traditional optimized sample and reference wavelengths for fat, protein, and lactose analysis as described by Kaylegian et al. (2009). Precalibration performance of the mid-IR milk analyzer was evaluated and controlled as described by Barbano and Clark (1989) and Lynch et al. (2006). Calibration of the mid-IR milk analyzer was done using modified milk calibration samples with all-laboratory mean chemistry reference values, as described by Kaylegian et al. (2006a,b). For milk component testing, sample 1 for IR only, sample 1 for TBC, and sample 1 for $\mathrm{TBC}+\mathrm{PI}$ were tested twice in sequence for each vial in a group of 3 vials in that order using a Lactoscope 400 FTIR (Delta Instrument, Drachten, the Netherlands); this was done for each sample number. The IR only, TBC, and TBC+PI samples were run consecutively on the IR for the same sample number (i.e., 1,2 , and so on). The order of testing sample numbers (i.e., 1 to 20 ) on the IR was randomized within each fat level (i.e., the 3 batches of 20 samples) so they would not be tested in the same order as they were tested on the BactoScan. The order of IR testing blocks (i.e., sample number 1 to 20) of the 3 milks in a block was also different from one FL to the next. Randomizing the testing order negated any zero drift on the IR during a batch and eliminated any correlation between the order of running the samples on the BactoScan with the order of testing on the IR and order of running correlation among FL. The IR milk analyzer was zeroed after each fat level run was completed (i.e., 120 milk uptake cycles). All IR testing was done on the same IR milk analyzer to focus on the effect of prior TBC and PI counting on IR milk component test results.

\section{RESULTS AND DISCUSSION}

\section{Initial Milk Composition}

The initial composition of the milk for each fat level and for each laboratory is shown in Table 2. The FL were approximately 2, 3, 4, and $5 \%$. As fat content increased, true protein and anhydrous lactose content decreased as expected. The milk SCC increased from approximately 10,000 cells/mL in FL1 to 800,000 cells/ $\mathrm{mL}$ in FL4 with increasing fat content as expected (data not shown) due to the rising of the somatic cells during gravity separation (Caplan et al., 2013; Geer and Barbano, 2014a,b). The initial bacteria count of the bulk raw milks varied, as expected, from approximately 3 to $48 \times 10^{3} \mathrm{cfu} / \mathrm{mL}$ based on bacteria counts determined with the Petrifilm method (Wehr and Frank, 2004: method 6.040).

\section{Analysis of IR Data Combined From All 3 Laboratories}

TBC and PI Count. A difference in TBC from one batch of milk to another was observed, with the starting batch of raw milk used for laboratory 3 having a much higher bacteria count (about $48 \times 10^{3} \mathrm{cfu} /$ $\mathrm{mL}$ ) than the milk used for testing in laboratory 1 or 2 (Table 3). The TBC of milks tested in laboratory 3 for FL2, FL3, and FL4 were above the limit for grade A $(>100,000 \mathrm{cfu} / \mathrm{mL})$ farm milk. The TBC increased with increasing FL, as expected (Caplan et al., 2013; Geer and Barbano, 2014a,b), because of the use of increasing amounts of gravity cream layer 6 with a high bacteria count. Laboratories 1 and 3 had a higher $(P<0.05)$ PI count, at each FL than laboratory 2 (Table 3). The TBC for laboratory 1 was similar to that of laboratory 2 , but the PI count for laboratory 1 was much higher $(P<0.05)$ than laboratory 2 . This indicated that the raw milk microflora in the batch of raw milk used for laboratory 1 had much more growth at 13 to $14^{\circ} \mathrm{C}$ in $18 \mathrm{~h}$ than the raw milk microflora in the batch of milk used for laboratory 2.

IR Analysis Data. Overall, the $\mathrm{R}^{2}$ values for the 4 ANOVA models were low (Table 4 ), with the highest for fat $\mathrm{A}$, but the $\mathrm{F}$-tests for the overall models were significant $(P<0.05)$. The data for type III sum of squares in Table 4 are expressed as a percentage of the total type III sum of squares to make it easy to see how much of the total variation in the data was explained by each term in the ANOVA model. The significant ef- 
Table 3. Mean $(\mathrm{n}=20)$ total bacteria count $(\mathrm{TBC} ; \mathrm{cfu} / \mathrm{mL})$ and preliminary incubation $(\mathrm{PI})$ count $(\times 1,000$ $\mathrm{cfu} / \mathrm{mL}$ ) determined with a BactoScan FC (Foss Electric, Hillerød, Denmark) for each replicate [laboratory (Lab) 1, 2, and 3]

\begin{tabular}{|c|c|c|c|c|c|c|}
\hline \multirow{2}{*}{$\begin{array}{l}\text { Fat level } \\
(\mathrm{FL})\end{array}$} & \multicolumn{3}{|c|}{ TBC } & \multicolumn{3}{|c|}{ PI count } \\
\hline & Lab 1 & Lab 2 & Lab 3 & Lab 1 & Lab 2 & Lab 3 \\
\hline FL1 & 1 & 1 & 22 & 69 & 1 & $>300$ \\
\hline FL2 & 8 & 2 & 567 & $>300$ & 8 & $>300$ \\
\hline FL3 & 23 & 6 & 1,507 & $>300$ & 37 & $>300$ \\
\hline FL4 & 35 & 11 & 2,200 & $>300$ & 36 & $>300$ \\
\hline
\end{tabular}

fect of laboratory (Table 4) reflects the combined influence of the different batch of milk (primarily differences from batch to batch in milk microflora) used for each laboratory and the difference in BactoScan instrument from one laboratory to the next. Treatment was significant $(P<0.05)$ for all 4 IR measures of composition; however, interactions $(P<0.05)$ of FL by treatment and laboratory by treatment were also observed for all 4 IR measures of milk composition.

The overall effects of treatment on differences in mean IR results from all labs combined are shown in Table 5 in the All labs column. The mean IR measurements for the contrast of IR only with TBC + PI for the mean of all labs were different $(P<0.05)$ from IR only for fat A, lactose, and true protein. In contrast, for IR only versus TBC for all laboratories only 1 of the 4 IR measures (i.e., fat B) was different $(P<0.05)$. Thus, when looking at the overall data set average for the 3 laboratories, the effect of the incubation step for doing the TBC+PI count had a much larger effect on the IR results than TBC only. This is confirmed by the fact that the percentage of total type III sum of square variation in the IR data that was explained by the interaction term of laboratory by treatment (Table 4), which explains the largest percentage of the type III sum of square variation in the component data. The fact that effect of FL did not stand out prominently to explain a large percentage of the variation in the ANOVA (Table 4) indicates that the cold mixing and sampling of the milk done by the operator and the BactoScan was removing a representative test portion from each container. If the BactoScan was not removing a representative test portion from the sample vial, a much higher percentage of total variation in type III sum of square should have been seen for FL for fat $\mathrm{B}$ and fat $\mathrm{A}$ along with no effect on lactose and protein (Table 4); this was not observed. To more clearly see the effects of treatment and FL, the ANOVA was performed separately on the data for each individual laboratory.

\section{Analysis of IR Data by Individual Laboratory}

The results of the ANOVA of the IR data done for the data for each individual laboratory are shown in Tables 5 and 6 and Figures 3, 4, 5, and 6. When significant effects $(P<0.05)$ were observed, treatment and the interaction of treatment by FL explained most of the variation in differences between IR only and the IR results for component analysis for the TBC and TBC+PI treatments (Table 6); the mean test differences are shown in Table 7.

Table 4. Sum of squares (type III SS) expressed as a percentage of the total type III SS and probability values (in parentheses) for the ANOVA for the effect of laboratory (Lab), fat level (FL), treatment (T) mid-infrared (IR) only, total bacteria count (TBC), and $\mathrm{TBC}+$ preliminary incubation count (PI) and interactions, on the difference for IR value for fat B, fat A, anhydrous lactose, and true protein for the data combined across all 3 laboratories

\begin{tabular}{|c|c|c|c|c|c|}
\hline \multirow[b]{2}{*}{ Factor } & \multirow[b]{2}{*}{ df } & \multicolumn{3}{|c|}{ Difference from IR value } & \multirow{2}{*}{$\begin{array}{l}\text { True } \\
\text { protein }\end{array}$} \\
\hline & & Fat B & Fat A & Lactose & \\
\hline \multicolumn{6}{|l|}{ Whole plot } \\
\hline Lab & 2 & $3.71^{*}(<0.01)$ & $7.15^{*}(<0.01)$ & $6.16^{*}(<0.01)$ & $5.97^{*}(<0.01)$ \\
\hline FL & 3 & $0.55^{*}(0.195)$ & $3.08^{*}(<0.01)$ & $2.49 *(<0.01)$ & $2.04^{*}(<0.01)$ \\
\hline Treatment & 2 & $2.75^{*}(<0.01)$ & $10.78^{*}(<0.01)$ & $4.15^{*}(<0.01)$ & $1.54^{*}(<0.01)$ \\
\hline $\mathrm{Lab} \times \mathrm{FL}$ & 6 & $3.33^{*}(<0.01)$ & $4.58^{*}(<0.01)$ & $3.82 *(<0.01)$ & $1.45 *(0.04)$ \\
\hline $\mathrm{Lab} \times \mathrm{T}$ & 4 & $5.22 *(<0.01)$ & $13.99^{*}(<0.01)$ & $4.95^{*}(<0.01)$ & $10.38^{*}(<0.01)$ \\
\hline $\mathrm{FL} \times \mathrm{T}$ & 6 & $2.96^{*}(<0.01)$ & $2.95^{*}(<0.01)$ & $1.49^{*}(<0.01)$ & $3.00^{*}(<0.01)$ \\
\hline $\mathrm{R}^{2}$ & & 0.1853 & 0.4257 & 0.2305 & 0.2438 \\
\hline Error term & & 81.47 & 57.47 & 76.95 & 75.62 \\
\hline
\end{tabular}


Table 5. Least squares means values of the difference from mid-infrared (IR) value for fat B, fat A, anhydrous lactose, and true protein for laboratories (Lab) 1, 2, 3, and the mean for all laboratories for IR only, total

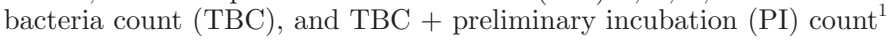

\begin{tabular}{|c|c|c|c|c|}
\hline Treatment & Lab 1 & Lab 2 & Lab 3 & All labs \\
\hline \multicolumn{5}{|l|}{ Fat B } \\
\hline IR only & $0.0000^{\mathrm{b}}$ & $0.0000^{\mathrm{a}}$ & $0.0000^{\mathrm{a}}$ & $>-0.0000^{\mathrm{b}}$ \\
\hline TBC & $-0.0045^{\mathrm{bc}}$ & $-0.0006^{\mathrm{ab}}$ & $-0.0134^{\mathrm{b}}$ & $-0.0060^{\mathrm{a}}$ \\
\hline $\mathrm{TBC}+\mathrm{PI}$ & $0.0012^{\mathrm{a}}$ & $-0.0038^{\mathrm{b}}$ & $-0.0107^{\mathrm{b}}$ & $0.0009^{\mathrm{b}}$ \\
\hline \multicolumn{5}{|l|}{ Fat A } \\
\hline IR only & $0.0000^{\mathrm{a}}$ & $0.0000^{\mathrm{a}}$ & $0.0000^{\mathrm{a}}$ & $0.0000^{\mathrm{a}}$ \\
\hline TBC & $-0.0054^{\mathrm{b}}$ & $0.0014^{\mathrm{a}}$ & $-0.0128^{\mathrm{b}}$ & $-0.0055^{\mathrm{a}}$ \\
\hline $\mathrm{TBC}+\mathrm{PI}$ & $-0.0525^{\mathrm{c}}$ & $-0.0031^{\mathrm{b}}$ & $-0.0160^{\mathrm{b}}$ & $-0.0214^{\mathrm{b}}$ \\
\hline \multicolumn{5}{|l|}{ Lactose } \\
\hline IR only & $0.0000^{\mathrm{a}}$ & $0.0000^{\mathrm{b}}$ & $0.0000^{\mathrm{a}}$ & $0.0000^{\mathrm{a}}$ \\
\hline $\mathrm{TBC}$ & $-0.0021^{\mathrm{a}}$ & $0.0019^{\mathrm{b}}$ & $-0.0061^{\mathrm{b}}$ & $-0.0044^{\mathrm{a}}$ \\
\hline $\mathrm{TBC}+\mathrm{PI}$ & $-0.0148^{\mathrm{b}}$ & $0.0058^{\mathrm{a}}$ & $-0.0206^{\mathrm{b}}$ & $0.0013^{\mathrm{b}}$ \\
\hline \multicolumn{5}{|l|}{ True protein } \\
\hline IR only & $0.0000^{\mathrm{a}}$ & $0.0000^{\mathrm{a}}$ & $0.0000^{\mathrm{a}}$ & $>-0.000^{\mathrm{b}}$ \\
\hline $\mathrm{TBC}$ & $-0.0000^{\mathrm{a}}$ & $0.0010^{\mathrm{a}}$ & $-0.0034^{\mathrm{a}}$ & $-0.0003^{b}$ \\
\hline $\mathrm{TBC}+\mathrm{PI}$ & $0.0188^{b}$ & $0.0016^{\mathrm{a}}$ & $-0.0098^{\mathrm{b}}$ & $0.0039^{\mathrm{a}}$ \\
\hline
\end{tabular}

${ }^{\mathrm{a}-\mathrm{c}}$ Treatments within a laboratory and within all laboratories for each milk component not sharing the same superscript are different $(P<0.05)$.

${ }^{1}$ Significant effect of the treatments TBC and TBC + PI on the mean $(\mathrm{n}=20)$ infrared test.

\section{Effect of Microbial Test on Each Milk Component Measurement}

Fat $\boldsymbol{B}$. The fat B measurement is primarily based on the carbon hydrogen stretch within FA chains of milk fat. Fat level, treatment, and FL by treatment interaction were significant for the data from all 3 laboratories. The effect of treatment (i.e., TBC or TBC + PI) and treatment by FL interaction on IR fat B test results explained the largest percentage of the variation (Table 6) in fat B results. The effect of TBC+PI testing (Table 7 and Figure 3b) was generally larger than TBC alone (Table 7 and Figure 3a). The TBC+PI testing caused the fat $\mathrm{B}$ results in laboratories 1 and 3 to deviate from the IR only in opposite directions (Table 7 and Figure $3 \mathrm{~b}$ ) and the magnitude of the difference increased with FL and TBC. The fact that TBC+PI treatments in laboratories 1 and 3 caused the fat $\mathrm{B}$ IR results to deviate in opposite directions is an indication that metabolites due to microbial growth in the samples for laboratory 1 and 3 were different and had a different influence on the IR absorbance spectra of the milk sample at the wavelengths used in the fat B measurement.

Fat $\boldsymbol{A}$. The fat A measurement is primarily based on the carbonyl stretch within triglycerides of milk fat. Fat level, treatment, and FL by treatment interaction were significant for the data from all 3 laboratories. The effect of treatment (i.e., TBC or $\mathrm{TBC}+\mathrm{PI}$ ) and treatment by FL interaction on IR fat A test results explained the largest percentage of the variation (Table 6 ). The effect of TBC+PI testing (Table 7 and Figure 4b) was larger than TBC alone (Table 7 and Figure 4a).
The TBC+PI testing caused the fat A results in laboratories 1 and 3 to deviate $(P<0.05)$ from the IR only by the largest amount (Table 7 and Figure 4b), but the magnitude did not consistently increase with increasing fat level, indicating that the effect was due more to microbial growth than nonrepresentative sampling of fat. The fact that $\mathrm{TBC}+\mathrm{PI}$ treatments in laboratories 1 and 3 caused the fat A IR results to deviate the most is consistent with their higher microbial counts than the samples for laboratory 2 (Table 3 ). The fact that the effect of TBC+PI on fat $\mathrm{B}$ caused the fat results to be higher than IR only in laboratory 1 (Figure $4 \mathrm{~b}$ and Table 7), along with the effect of TBC+PI on fat A caused the fat results lower than IR only in laboratory 1 , again supports the hypothesis that the growth of bacteria in the milk sample and absorption of light by the microbial metabolites influenced the accuracy of the IR measurement of fat. The difference between fat B (carbon hydrogen stretch) and fat A (carbonyl stretch) measurements of fat in the same sample at the highest fat content was about $0.1 \%$ fat in laboratory 1 . Different behavior was seen in each laboratory and would depend on the type of bacteria growing in the milk and the type of microbial metabolites produced. In testing individual farm milks, the characteristics of the effect of microbial growth could be different in every sample. The present study was designed to detect these effects but not exhaustively explore the extremes of the effect of the growth of different microbial populations that could be present in the population of raw milk samples.

Anhydrous Lactose. The effect of treatment on IR lactose results was significant $(P<0.05)$ in all 3 laboratories (Table 6), with the largest (about -0.02 
Table 6. Sum of the squares (type III SS) expressed as a percentage of the total type III SS and probability values (in parentheses) for the ANOVA of the effect of fat level (FL), treatment [mid-infrared (IR) only, total bacteria count (TBC), and TBC + preliminary incubation count $(\mathrm{PI})$, and the interaction of $\mathrm{FL} \times$ treatment, on the difference from IR value for fat $\mathrm{B}$, fat $\mathrm{A}$, anhydrous lactose, and true protein for laboratories (Lab) 1,2 , and 3 , separately

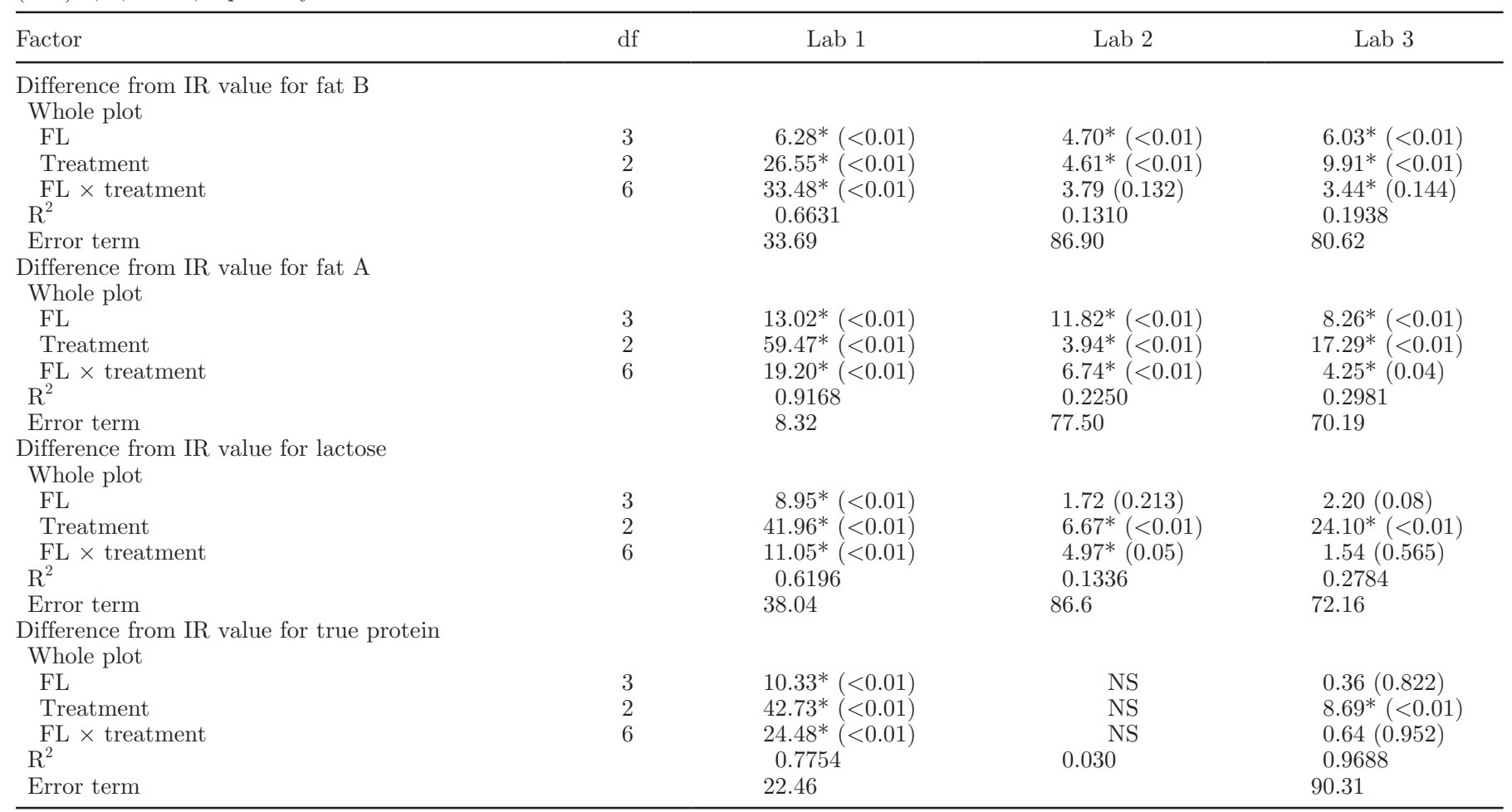

$* P<0.05$.

Table 7. Least squares means values of the difference from mid-infrared (IR) value for fat B, fat A, anhydrous lactose, and true protein for laboratories (Lab) 1, 2, and 3, for fat level (FL1, FL2, FL3, and FL4), for the interaction fat level $\times$ treatment [total bacteria count (TBC) and $\mathrm{TBC}+$ preliminary incubation count $(\mathrm{PI})]$

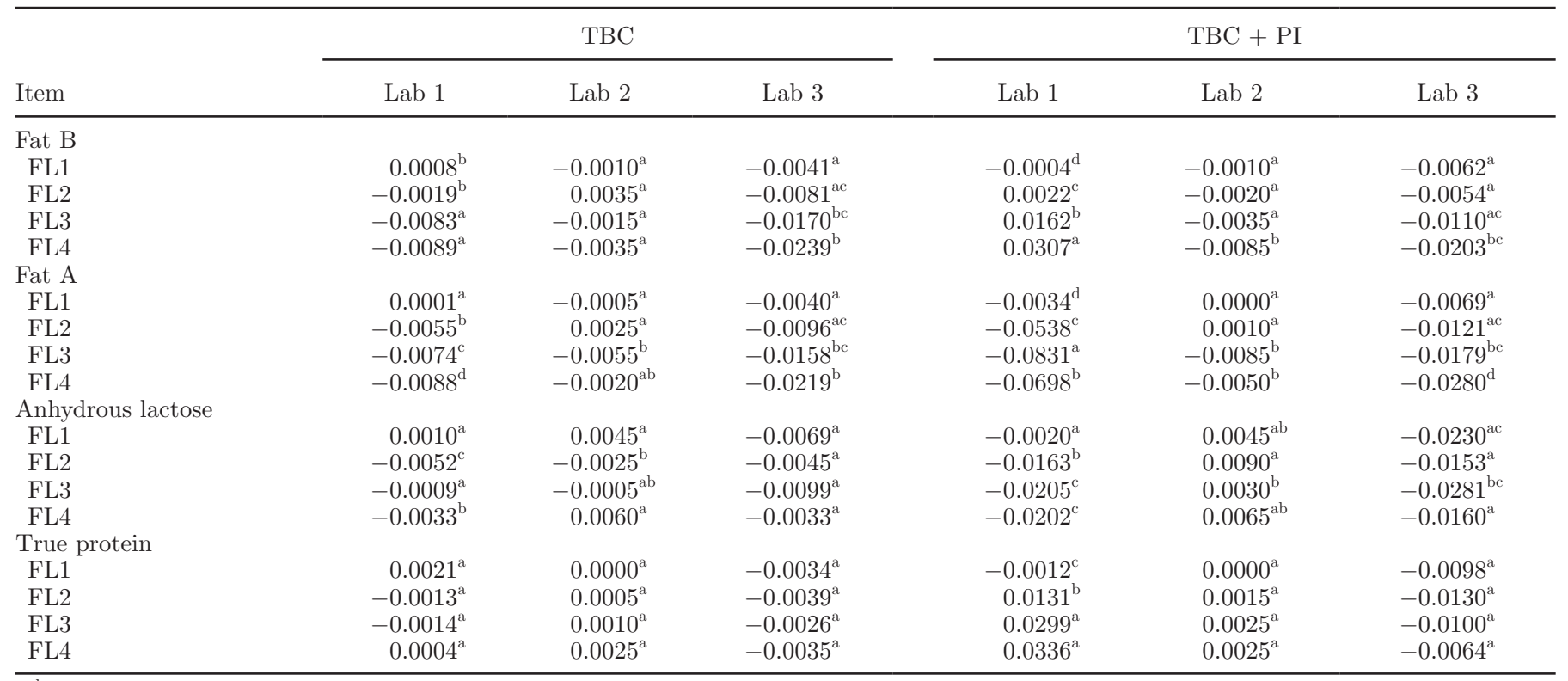

${ }^{\mathrm{a}-\mathrm{d}}$ Fat level within treatments within a laboratory not sharing the same superscript are different $(P<0.05)$. 


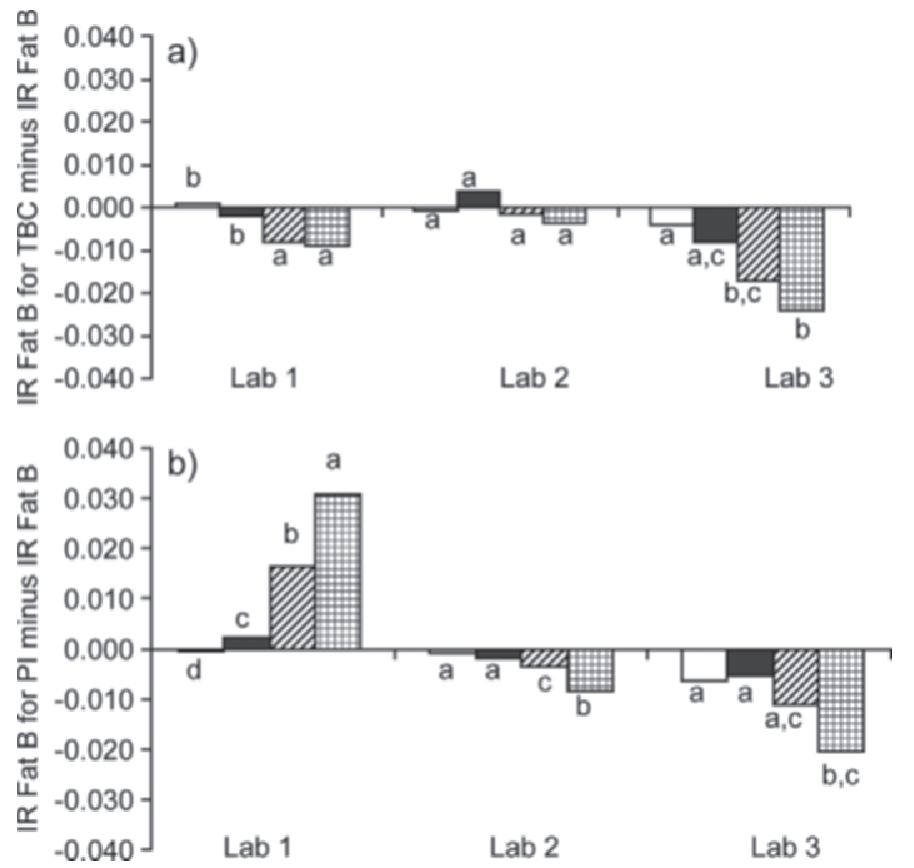

Figure 3. (a) Effect of total bacteria count (TBC) treatment sampling handling on change in mid-infrared (IR) fat B readings for fat level 1 (white bar), 2 (black bar), 3 (striped bar), and 4 (hashed bar) for each laboratory (1,2, and 3). (b) Effect of $\mathrm{TBC}+$ preliminary incubation (PI) count on change in IR fat B readings for fat level 1 (white bar), 2 (black bar), 3 (striped bar), and 4 (hashed bar) for each laboratory $(1,2$, and 3$)$. Fat levels within treatments within a laboratory not sharing the same letter $(\mathrm{a}-\mathrm{d})$ are different $(P<0.05)$.

to $-0.03 \%)$ effect $(P<0.05)$ due to $\mathrm{TBC}+\mathrm{PI}$ seen in laboratories 1 and 3 (Table 7 and Figure 5b) where microbial growth (Table 3 ) in the samples was the highest. The effect of TBC testing on IR lactose measurement was less than $0.01 \%$ in all laboratories at all $\mathrm{FL}$ (Table 7 and Figure 5a). Bacterial growth for the PI test (Table 3) caused the IR lactose readings to decrease significantly $(P<0.05)$ at all FL (Figure 5b), regardless of FL (i.e., 1, 2, 3 or 4 ).

True Protein. The effect of treatment on IR true protein results was significant $(P<0.05)$ in 2 of 3 laboratories (Table 6), with the largest (about $0.03 \%$ ) effect $(P<0.05)$ due to TBC+PI seen in laboratory 1 at FL3 (Table 7 and Figure 6b), where microbial growth (Table 3) in the samples was the highest. Whereas the microbial growth was also high in the PI samples for laboratory 3 (Table 3 ), no difference $(P>0.05)$ in true protein test was detected. This may be due to the fact that differences in the types of compounds produced by microbial growth will differ from one microbial population to another and they may or may not absorb IR light in a region of the mid-IR spectra that will cause a detectable change in results. True protein results of laboratory 2 were not affected $(P>0.05)$ by treatment
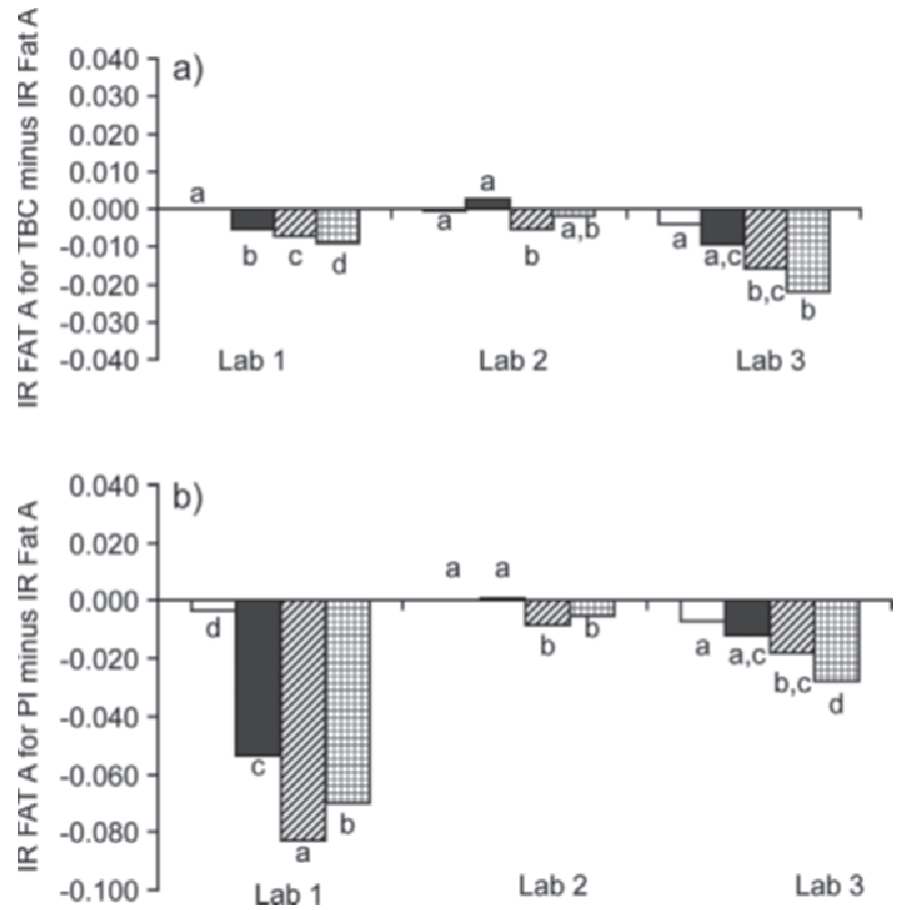

Figure 4. (a) Effect of total bacteria count (TBC) treatment sampling handling on change in infrared (IR) fat A readings for fat level 1 (white bar), 2 (black bar), 3 (striped bar), and 4 (hashed bar) for each laboratory $(1,2$, and 3$)$. (b) Effect of $\mathrm{TBC}+$ preliminary incubation count (PI) on change in IR fat A readings for fat level 1 (white bar), 2 (black bar), 3 (striped bar), and 4 (hashed bar) for each laboratory (1, 2 , and 3$)$. Fat levels within treatments within a laboratory not sharing the same letter $(\mathrm{a}-\mathrm{d})$ are different $(P<0.05)$.

(Table 6) and samples for that laboratory had the least microbial growth (Table 3). The effect of TBC testing on IR true protein measurement was less than $0.01 \%$ in all laboratories at all FL (Table 7 and Figure 6a).

\section{Practical Implications}

The wavelengths for fat, protein, and lactose measurement used in the current study were the traditional optimized IR sample and reference wavelengths reported by Kaylegian et al. (2009). Use of well-defined traditional sample and reference wavelengths is the simplest and most controlled situation in IR milk analysis, and that approach was used in the current study. Newer PLS-based mid-IR prediction models for measurement of fat, protein, and lactose content of milk use different and more wavelengths than the traditional approach. The wavelengths used in PLS calibrations are not standardized from one instrument manufacturer to another and can differ in different versions of PLS prediction models from the same manufacturer. The information about wavelengths used in PLS models is proprietary to each instrument manufacturer and differs from one 

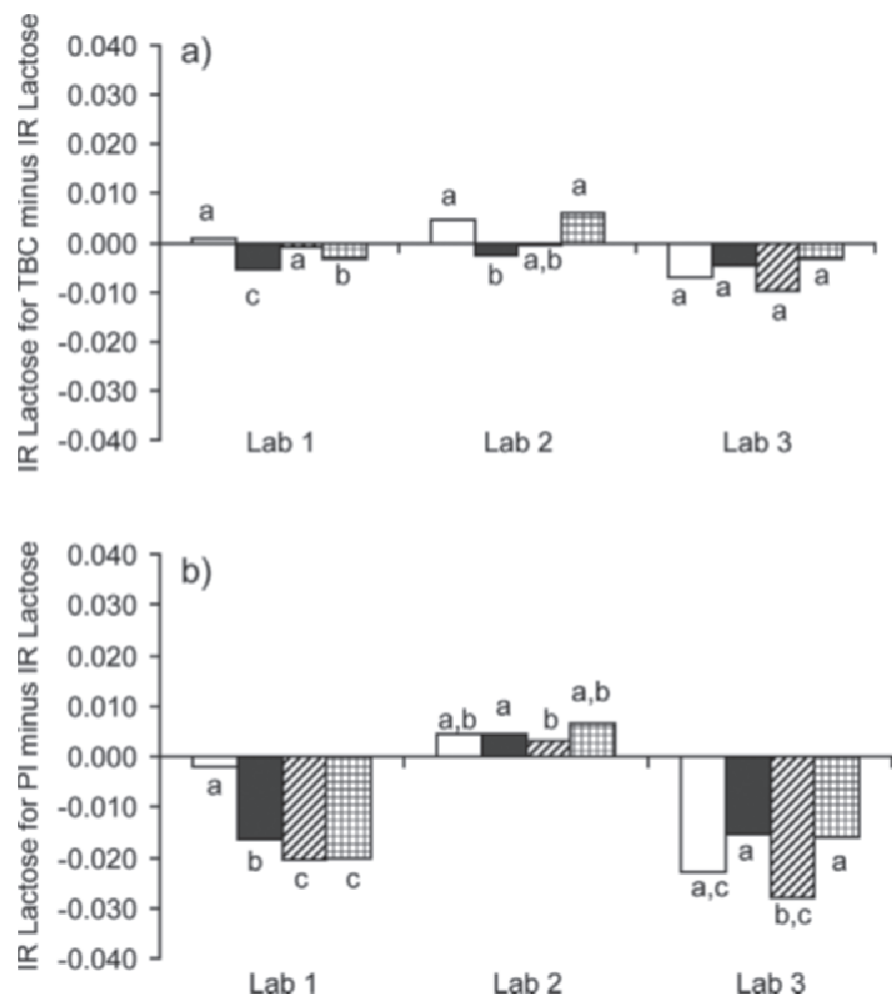

Figure 5. (a) Effect of total bacteria count (TBC) treatment sampling handling on change in infrared (IR) lactose readings for fat level 1 (white bar), 2 (black bar), 3 (striped bar), and 4 (hashed bar) for each laboratory $(1,2$, and 3$)$. (b) Effect of TBC + preliminary incubation count (PI) on change in IR lactose readings for fat level 1 (white bar), 2 (black bar), 3 (striped bar), and 4 (hashed bar) for each laboratory $(1,2$, and 3$)$. Lactose levels within treatments within a laboratory not sharing the same letter $(\mathrm{a}-\mathrm{c})$ are different $(P<0.05)$.

manufacturer to another. Use of more wavelengths increases the probability that microbial growth in milk samples, particularly when incubating milk samples at 13 to $14^{\circ} \mathrm{C}$ for $18 \mathrm{~h}$ for PI testing, will have more and varied effects on the accuracy of IR milk component testing results.

\section{CONCLUSIONS}

No large effect on the accuracy of component milk testing (IR fat B and fat A) due to the cold milk sample handling and mixing procedures used in $\mathrm{TBC}$ in the present study was detected, confirming the fact that the physical removal of milk from the vial by the BactoScan FC was a representative portion of the milk sample. However, the representativeness of any other sampling procedure (manual or automated) of a cold milk sample before running milk component testing on the same milk sample should be demonstrated and verified periodically as a matter of routine laboratory quality assurance. Running TBC with a BactoScan FC first and then IR milk analysis after had minimal effect
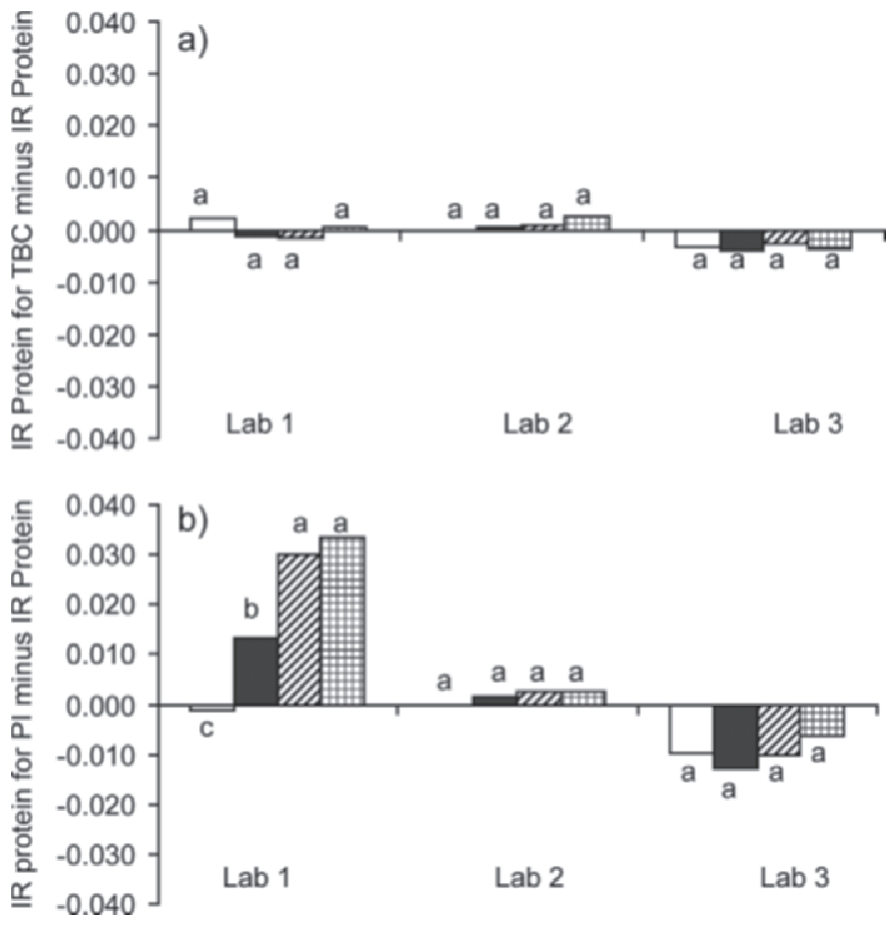

Figure 6. (a) Effect of total bacteria count (TBC) treatment sampling handling on change in mid-infrared (IR) true protein readings for fat level 1 (white bar), 2 (black bar), 3 (striped bar), and 4 (hashed bar) for each laboratory (1,2, and 3). (b) Effect of TBC + preliminary incubation (PI) count on change in IR true protein readings for fat level 1 (white bar), 2 (black bar), 3 (striped bar), and 4 (hashed bar) for each laboratory $(1,2$, and 3 ). Protein levels within treatments within a laboratory not sharing the same letter $(\mathrm{a}-\mathrm{c})$ are different $(P<0.05)$.

$(<0.01 \%)$ on milk component tests by IR when milk bacteria counts were within pasteurized milk ordinance limits of less than the $100,000 \mathrm{cfu} / \mathrm{mL}$ limit. Running raw milk PI counts ( $18 \mathrm{~h}$ of incubation at 13 to $14^{\circ} \mathrm{C}$ ) with the BactoScan FC before milk component testing by mid-IR milk analysis had an effect $(P<0.05)$ on component tests. The effect was the largest on fat test results and would decrease the accuracy of milk payment testing on individual producer milk samples. The effect was most likely due to the absorption of light by bacterial metabolites produced during the PI count incubation, not by the sampling procedure of the BactoScan. The direction of the effect on component test result will vary depending on the bacteria count and the type of bacteria that grew in the milk, and this could be different in every individual producer milk sample.

\section{ACKNOWLEDGMENTS}

The authors thank the USDA Federal Milk Markets and the Northeast Dairy Foods Research Center for partial funding of this research and Cornell University 
(Ithaca, NY) staff members Sara Bova, Chassidy Coon, and Michelle Bilotta for their technical assistance and Steve Murphy for help with the history of changes in the Pasteurized Milk Ordinance and actions of the National Conference on Interstate Milk Shipments.

\section{REFERENCES}

AOAC International. 2000. Official Methods of Analysis. 17th ed. AOAC International, Gaithersburg, MD.

Barbano, D. M. 1992. Raw milk quality: Milk quality improvement in the United States. Pages 3-6 in Proc. Conf. Milk Qual. Cheese Making. CSIRO Dairy Research Center, Highett, Victoria, Australia. CSIRO, Werribee, VIC, Australia.

Barbano, D. M., and J. L. Clark. 1989. Infrared milk analysis: Challenges for the future. J. Dairy Sci. 72:1627-1636.

Barbano, D. M., and M. E. DellaValle. 1987. Rapid infrared method for determination of casein content of milk. J. Dairy Sci. 70:15241528.

Barbano, D. M., Y. Ma, and M. V. Santos. 2006. Influence of raw milk quality on fluid milk shelf life. J. Dairy Sci. 89:E15-E19.

Barbano, D. M., K. L. Wojciechowski, and J. M. Lynch. 2010. Impact of preservatives on the accuracy of milk component measurement by mid-infrared milk analyzers. J. Dairy Sci. 93:6000-6011.

Bishop, J. R. 1989. The preliminary incubation count-Is it good enough? Dairy Food Environ. Sanitation. 9:122-124.

Caplan, Z., C. Melilli, and D. M. Barbano. 2013. Gravity separation of fat, somatic cells, and bacteria in raw and pasteurized milks. J. Dairy Sci. 96:2011-2019.

Everson, T. C. 1988. Quality and protein incentive programs for Wisconsin Dairy Cooperatives. Page 55 in Proc. 27th Ann. Natl. Mastitis Counc. Mtg., National Mastitis Council, Arlington, VA. National Mastitis Council, Verona, WI.

Geer, S. R., and D. M. Barbano. 2014a. Effect of colostrum on gravity separation of milk somatic cells in skim milk. J. Dairy Sci. 97:687-693

Geer, S. R., and D. M. Barbano. 2014b. The effect of immunoglobulins and somatic cells on the gravity separation of fat, bacteria, and spores in pasteurized whole milk. J. Dairy Sci. 97:2027-2038.

Geyer, J. E. 1990. Premiums make a difference. Pages 14 to 22 in Proc. 29th Ann. Mtg. Natl Mastitis Counc. Inc., 1840 Wilson Boulevard, Arlington, VA

Kaylegian, K. E., G. E. Houghton, J. M. Lynch, J. R. Fleming, and D. M. Barbano. 2006a. Calibration of infrared milk analyzers: Modified milk versus producer milk. J. Dairy Sci. 89:2817-2832.

Kaylegian, K. E., J. M. Lynch, J. R. Fleming, and D. M. Barbano. 2007. Lipolysis and proteolysis of modified and producer milks used for calibration of mid-infrared milk analyzers. J. Dairy Sci. 90:602-615.

Kaylegian, K. E., J. M. Lynch, J. R. Fleming, and D. M. Barbano 2009. Influence of fatty acid chain length and unsaturation on midinfrared milk analysis. J. Dairy Sci. 92:2485-2501.

Kaylegian, K. E., J. M. Lynch, G. E. Houghton, J. R. Fleming, and D. M. Barbano. 2006b. Modified versus producer milk calibration: Mid-infrared analyzer performance validation. J. Dairy Sci 89:2833-2845.

Kerkhof-Mogot, M. F., J. Koops, R. Neeter, K. J. Slangen, H. van Hemert, O. Kooyman, and W. Wooldrik. 1982. Routine testing of farm tank milk with the Milko-Scan 203. I. Calibration procedure and small-scale experiments. Neth. Milk Dairy J. 36:115-133.

Lynch, J. M., D. M. Barbano, M. Schweisthal, and J. R. Fleming. 2006. Precalibration evaluation procedures for mid-infrared milk analyzers. J. Dairy Sci. 89:2761-2774.

Ma, Y., D. M. Barbano, J. Hotchkiss, and S. Murphy. 2001. Impact of $\mathrm{CO}_{2}$ addition to milk on selected analytical testing methods. J. Dairy Sci. 84:1959-1968.
Ma, Y., C. Ryan, D. M. Barbano, D. M. Galton, M. A. Rudan, and K. J. Boor. 2000. Effects of somatic cell count on quality and shelf-life of pasteurized fluid milk. J. Dairy Sci. 83:264-274.

Marshall, R. T., ed. 1992. Standard Methods for the Examination of Dairy Products. 16th ed. American Public Health Association, Washington, DC

Marth, E. H., ed. 1978. Standard Methods for the Examination of Dairy Products. 14th ed. American Public Health Association, Washington, DC.

Martin, N. H., M. L. Ranieri, S. C. Murphy, R. D. Ralyea, M. Wiedmann, and K. J. Boor. 2011. Results from raw milk microbiological tests do not predict the shelf-life performance of commercially pasteurized fluid milk. J. Dairy Sci. 94:1211-1222.

NCIMS (National Conference on Interstate Shipments). 2011. Bacto-scan industry operator (BIO) approval procedures protocol. Accessed Jun. 27, 2014. http://nysafp.com/wp-content/ uploads/2013/03/FORM-FDA-NCIMS-2400a-2-Foss-BactoScanFCx-BIO-Proto-rev.-03-11.pdf.

NCIMS (National Conference on Interstate Milk Shipments). 2013. Cultural procedures - General requirements. Accessed Jan. 25 , $2014 . \quad$ http://www.agriculture.state.pa.us/portal/server.pt/ gateway/PTARGS_0_2_24476_10297_0_43/AgWebsite/Files/ Forms/CulturalProceduresGeneralRequirementsrev1013.pdf.

Peeler, J. T., J. W. Messer, R. L. Sanders, and H. K. Bachelor. 1989. A comparison of preliminary incubation counts and standard plate counts of grade A farm bulk tank milk from eleven states. Dairy Food Environ. Sanitation 9:494-497.

Richardson, G. H., ed. 1985. Standard Methods for the Examination of Dairy Products. 15th ed. American Public Health Association, Washington, DC.

Robertson, N. H., A. Dixon, J. H. Nowers, and D. P. S. Brink. 1981 The influence of lipolysis, $\mathrm{pH}$ and homogenization on infra-red readings for fat, protein and lactose. S. Afr. J. Dairy Technol. $13: 3-7$.

Robinson, R. K. 2002. Quality control in the dairy industry. Pages 684-685 in Dairy Microbiology Handbook: The Microbiology of Milk and Milk Products, 3rd ed. Wiley Interscience, John Wiley and Sons, New York, NY

Ryan, J. J., R. H. Gough, and C. H. White. 1984. Preliminary incubation count as an index of raw milk microbiological quality during storage. J. Food Prot. 47:206-208.

Santos, M. V., Y. Ma, and D. M. Barbano. 2003a. Effect of somatic cell count on proteolysis and lipolysis in pasteurized fluid milk during shelf-life storage. J. Dairy Sci. 86:2491-2503.

Santos, M. V., Y. Ma, Z. Caplan, and D. M. Barbano. 2003b. Sensory threshold of off-flavors caused by proteolysis and lipolysis in milk. J. Dairy Sci. 86:1601-1607.

Schmitt, J., and H. Flemming. 1998. FTIR-spectroscopy in microbial and material analysis. Int. Biodeterior. Biodegradation 41:1-11.

Silverstein, R. M., and G. C. Bassler. 1967. Carboxylate anion. Page 91 in Spectrometric Identification of Organic Compounds. John Wiley and Sons Inc., New York, NY.

Suhren, G., J. Reichmuth, and H. G. Walte. 2001. Bacteriological quality of raw milk: Conversion of BactoScan-FC counts onto the scale of the official method. Milchwissenschaft 56:380-384.

van de Voort, F. R., S. Kermasha, J. P. Smith, B. L. Mills, and K. F. Ng- Kwai-Hang. 1987. A study of the stability of record of performance milk samples for infrared milk analysis. J. Dairy Sci. 70:1515-1523

Walte, H. G., G. Suhren, and J. Reichmuth. 2005. Bacteriological rawmilk quality: Factors influencing the relationship between colony- forming units and BactoScan-FC counts. Milchwissenschaft 60:28-31.

Wehr, H. M., and J. F. Frank, ed. 2004. Standard Methods for the Examination of Dairy Products. 17th ed. American Public Health Association, Washington, DC. 